\title{
EDITORIAL \\ INTERACCIÓN DEL DERECHO INTERNACIONAL Y EL ORDENAMIENTO INTERNO
}

El desarrollo cuantitativo y cualitativo del Derecho Internacional Público, tanto en relación a los ámbitos abordados como a los sujetos, es evidente. Esto desafía particularmente al sistema de fuentes y la responsabilidad internacional, dada la intensa interacción entre Derecho Internacional y derecho nacional. Atrás quedó el tiempo en que el Derecho Internacional era sólo un asunto entre Estados. La cada vez más profusa existencia de normas en materias, por ejemplo, de comercio internacional, medioambiente y derechos humanos, empujan la frontera del ordenamiento nacional para recepcionar y aplicar normas jurídicas que establecen derechos en favor de las personas. Los ordenamientos nacionales deben adecuarse a esta realidad, sintonizando con los actos soberanos que emanan de los propios estados al generar Derecho Internacional.

Nuestro país vive actualmente un proceso de reflexión en torno a cambios constitucionales. En ese contexto, la interacción entre el derecho interno y el internacional, se plantea como una oportunidad de análisis y mejoramiento. La reforma del 2005 fue un paso. Luego de 10 ańos, es posible realizar una evaluación y proponer líneas de discusión para perfeccionar nuestro texto constitucional.

La Constitución recoge parcialmente la interacción entre derecho interno y Derecho Internacional. Se remite a señalar límites en el ejercicio de potestades públicas (artículo 5), tópicos de competencias para la conducción de relaciones internacionales (artículo 32), aspectos procedimentales en la aprobación o rechazo de tratados y trámites anexos (artículo 54) así como confusamente los controles constitucionales posteriores (artículo 93). Y todo esto, reducido sólo a normas convencionales.

Sin perjuicio de la labor que la jurisprudencia ha asumido en la incorporación y aplicación de las fuentes consuetudinarias y los Principios del Derecho, se requieren claridades normativas mayores.

Si sólo nos referimos por ahora al derecho convencional, resulta imperioso dilucidar la cuestión de la jerarquía y de la adecuación. O dicho en otros términos, el efecto en el ámbito interno de los artículos 26 y 27 de la Convención de Viena sobre el Derecho de los Tratados, evitando atribuir significados donde la norma internacional no los establece. El punto de partida básico es la obligación de cumplimiento que pesa sobre el Estado al ratificar instrumentos internacionales. Ahora bien, observados los artículos mencionados, la obligación es estrictamente de cumplimiento. Aspectos de jerarquía, forma y mecanismos de incorporación o 
cumplimiento son un asunto que de no ser explicitado en la norma internacional queda a disposición del sistema interno.

La doctrina se empecina en la discusión sobre la jerarquía que nuestra Constitución establece para los tratados internacionales en materia de DDHH. Esta parece centrarse en un foco equivocado y no en lo esencial: la búsqueda de un sistema protector de derechos humanos o fundamentales. Si se reduce el espacio de análisis a los $\mathrm{DDHH}$, las lecturas mayoritarias sobre el punto y derivadas de las posibles interpretaciones del artículo $5^{\circ}$, van desde jerarquía supra legal pero infra constitucional y jerarquía constitucional.

Sin embargo la discusión de la jerarquía no parece una cuestión que defina lo medular en el respeto a los derechos humanos o fundamentales.

El artículo $5^{\circ}$ de la constitución refleja, sin que el constituyente derivado lo haya buscado, el contenido de la norma pacta sunt servanda del artículo 27 y del 26 de la Convención de Viena, dando cuenta de la convivencia jurídica entre normas de naturaleza nacional e internacional. El artículo nos señala que la actuación de órganos estatales tiene como límite "el respeto a los derechos esenciales que emanan de la naturaleza humana" sean de aquellos consignados en el catálogo constitucional o en los tratados internacionales vinculantes para Chile. Este artículo sólo nos indica el límite en el ejercicio de poderes, sin establecer qué norma debe ceder ante la otra. Esta forma de convivencia a que ordena la Constitución, es coherente con el sistema establecido por ejemplo, en la Convención Interamericana de $\mathrm{DDHH}$, la que señala en su artículo $2^{\circ}$, que los Estados están obligados a adecuar sus normas y prácticas a la convención "con arreglo a sus procedimientos constitucionales". Es decir, la propia Convención reconoce el debido respeto a las constituciones de los estados para realizar las adecuaciones y dar así cumplimiento, en último término, al artículo 26 y 27 de la Convención de Viena.

Previo a la vigencia y vinculación de la norma para el Estado (ratificación), son posibles sin duda controles constitucionales de todo tipo. Una vez ingresado, el deber que se abre para los órganos del Estado es el de armonizar la convivencia del derecho interno y el derecho convencional de los DDHH mediante controles o mecanismos de compatibilidad, a través de procesos interpretativos (elementos y criterios de hermenéutica constitucional e internacional para cada norma), que permitan armonizar las normas, respetando así los actos soberanos emitidos por el Estado: dictación de normas internas y vinculación a convenciones internacionales. La debida compatibilización de ambas normas fija el eje en lo esencial: el respeto a los derechos constitucionales y los contenidos en los tratados. Se trataría de mecanismos interpretativos y no de controles normativos. Este no es por lo tanto un problema de jerarquía que deba abordar la Constitución. Soluciones altamente protectoras, sin atribución de jerarquía constitucional u otra, se da en el sistema alemán por ejemplo. 
Donde una norma internacional tiene rango infraconstitucional, pero mediante procesos de compatibilización a través de interpretaciones armónicas, permite el cumplimiento de los señalados artículos 26 y 27 de la Convención de Viena. Recurrir a ficciones y creaciones que exceden los márgenes aceptables de interpretación, como el recurso de convencionalidad, no sólo son innecesarios, si no que además entorpecen la creación de sistemas jurídicos coherentes en materia de DDHH que incluyen adecuadas convivencias y vasos comunicantes entre las normas convencionales y constitucionales existentes.

Una positivización constitucional sobre el deber de compatibilización mediante procesos hermenéuticos tanto de normas constitucionales como internacionales convencionales, ejercidos sea difusamente o bien de manera concentrada, abren un camino respetuoso de dos actos soberanos del Estado: la dictación de sus normas, y en el caso chileno normas con legitimación democrática, así como la voluntaria vinculación a normas convencionales internacionales.

Dra. María ANGÉlica BENAVIdes*

* Profesora de Derecho Internacional Público. Directora de Investigación Facultad de Derecho Universidad Finis Terrae (Chile). 
